\author{
Wiesław Staśkiewicz, Tomasz Stawecki \\ University of Warsaw
}

\title{
Legal Databases and Their Functions in the Process of Interpreting and Applying the Law
}

\begin{abstract}
This article deals with the implications of the widespread practice of use of legal databases in Polish judicial practice. Apart from the undeniable positive effects of development of an electronic civilization, the article deals with the negative effects of use of databases. This is because a conflict arises between the possibilities offered by the latest technology in the form of easy access to legal texts, commentaries and thousands of judicial rulings, and the unique historical experience of the judiciary in a former communist country, methods of legal interpretation sustained by legal positivism, and domination by a syllogistic model for application of the law. All results in dysfunction of legal databases. A kind of "hybrid interpretation of law" is formed, which is a combination of a legacy, the effects of transformation of the economy and the system, as well as the new rules of law, on the one hand, and the ideology of bound judicial decision on the other. The nature of the "hybrid interpretation of law" is the infinite scope for citing judicial rulings and commentaries available in the databases without taking a broader theoretical view - without supporting arguments, and so the citing of a ruling has become the basis for adjudication. The question of whether the possibilities that electronic databases offer will cause interpretation of this kind to turn into a new form of legal rhetoric, or whether it will remain merely a means of adaptation of the discretionary power of judges to legal positivism doctrine, and thus the sophism of the period of transformation, remains an open one.
\end{abstract}

\section{Setting the problem}

Nowadays, the use of electronic sources of legal information is a common practice. Three types of such sources are of greatest importance: legal databases, public records (public registries), as well as public and private websites.

The first type, legal databases, encompasses three categories of information: a) the wording of the provisions of the law (rules of positive law) which are in force in a given country or community, sometimes also no longer binding regulations, b) the content of judgments of various courts of a given country, especially the supreme or constitu- 
tional courts and courts of the higher instances, and sometimes also the content of rulings of the Court of Justice of the European Union and the European Court of Human Rights, as well as c) texts of the commentaries on individual provisions of the law, monographs, legal publications and opinions expressed by the science of law (legal doctrine). The second type of sources of legal information are public records (public registries) held in an electronic form by courts and central or local government administration. ${ }^{1}$ These are both public records, i.e. accessible to everybody, as well as registers with limited access, which are only accessible by judges, prosecutors, notaries public or employees of specific public offices. Finally, the third type of sources of legal information are public and private websites, established because of a legal obligation (for example, on the basis of the regulations on access to public information), or without such a requirement, for commercial, political or other purposes.

The widespread use of such electronic sources is currently so obvious that there is no point describing them in detail. ${ }^{2}$ It was interesting perhaps fifty years ago. ${ }^{3}$ Therefore, in this paper, we shall primarily focus only on the first type of source electronic databases assigned for lawyers. We are interested in sources of knowledge about law and how it operates. We also concentrate on consequences of the use of electronic legal databases in the process of interpreting and applying the law. We shall, however, not recommend any methods of interpreting the law; nor shall we justify the rightness of the choice of any method. We shall only perform a reconstruction and internal evaluation of judicial practice. Electronic legal databases are, however, merely an indirect source of information required by lawyers: they provide lawyers with collections of legal texts (provisions, judicial decisions), not with legal rules (norms). They are not able, as F. Studnicki noticed already in 1974, to derive rules through the process of legal interpretation. Therefore, interpretation of law plays and will play a crucial role. ${ }^{4}$

Having in mind the results of various research studies, as well as our own experience of the last twenty years, we set four main theses in this paper:

1) the use of electronic databases by lawyers, especially judges, serves better application of the law. Lawyers cannot use legal methods of the nineteenth century in a modern country with a democratic political system and a developed market economy. In this sense, new technologies support the traditionally understood principle of the rule of law. This opinion can be called "the necessity thesis". Admittedly, it is not particularly revealing, but it should not be ignored;

For general description see T. Stawecki, Rejestry publiczne. Funkcje instytucji [Eng. Public registries. Functions of the institution], Warszawa 2005. An example of legal reforms including the establishing of public records (registry) is presented in: T. Stawecki, Secured Transactions in Poland: Coping with the Traditional Thinking and the New Challenges for Central and Eastern Europe, "Uniform Commercial Code Law Journal” 1999/32/1.

2 In the Polish literature the issue is described in detail in: J. Janowski: Informatyka prawnicza [Eng. Informatics for lawyers], Warszawa 2011. See also: J. Janowski, Informatyka prawa. Zadania i znaczenie w związku z ksztattowaniem się elektronicznego obrotu prawnego [Eng. Legal informatics. Tasks and roles in connection with the development of electronic legal practice], Lublin 2011; D. Pietruch-Reizer, Rozwój środków przekazu informacji o prawie [Eng. Development of means of distribution of legal information], Katowice 1992, pp. $217 \mathrm{ff}$.

3 See G. Sartor, Introduction: ITC and Legislation In the Knowledge Society, in: Legislative XML for the Semantic Web. Principles, Models, Standards for Document Management, edited by. G. Sartor, M. Oalmirani, E. Francesconi, M. A. Biasiotti, Dordrecht - Heidelberg - London - New York 2011, pp. 7ff.; E. Francesconi, A Review of Systems and Projects: Management of Legislative Resources, in: Legislative XML for the Semantic Web..., pp. $173 \mathrm{ff}$.

4 F. Studnicki, Wstęp do informatyki prawniczej. Automatyczne systemy wyszukiwawcze [Eng. Introduction to legal informatics. Automatic search systems], Lublin 1974. See also F. Studnicki, Wprowadzenie do informatyki prawniczej. Zautomatyzowane wyszukiwanie informacji prawnej [Eng. Outline of legal informatics. Automatized search of legal information], Warszawa 1978, pp. 42ff., J. Janowski, Informatyka prawnicza..., p. 76. 
2) the use of electronic databases by lawyers has changed the methods of interpreting the law and legal reasoning compared with those recommended to date by the theory of the law and applied in court practice. This assertion can, in turn, be called "the relevancy thesis" because the use of databases proves to be an important factor of the interpretation policy of courts. Details of the nature and the scope of changes of the methods of legal interpretation and legal reasoning are elaborated hereunder;

3) while both of the arguments presented above might suggest a positive role of legal databases in the legal interpretation process, it is the observation of practice and empirical research ${ }^{5}$ that reveals dysfunctionalities of electronic databases. In the application of law, they are used in an attempt to break the impasse of judicial formalism (manifested most fully in the syllogistic model of application of law $)^{6}$ in favor of arguments based on jurisprudence and the principles and values of law.

However, the rulings of Polish courts and the Polish Constitutional Tribunal are not recognized as a source of law. Therefore, we face hardly limited discretionary power of courts: citing the argument of supposed case law "found" in legal databases, is not only deceptive - because in fact the cited rulings are neither legally binding precedents nor interpreted principles. They are cited merely for illustration, as well as for decorative and sophistic purposes. ${ }^{7}$ It is true that in Polish legal databases one can always find a judicial ruling which provides a desired interpretation of a provision, but that contributes little to the legal system. Citations taken from legal databases are illustration of literal interpretation of the law, but not the foundation for interpretation of the functions of law or purpose-oriented interpretations. ${ }^{8}$

In this manner, modern technologies promote a version of legal positivism which is not particularly modern. This assertion sounds paradoxical, and we propose calling it "the internal contradiction of functions thesis" of databases. In our opinion, this is the most important finding of our study of the role of electronic databases in legal practice;

4) finally, the fourth thesis is somewhat paradoxical in nature. It can be formulated as "the strong rooting thesis". This is because the action of even the newest institutions is determined by local traditions and legal culture of a given society. It transpires that the actual role of legal databases in a country like Poland is

D. Galligan, M. Matczak, Strategies of judicial review. Exercising judicial discretion in administrative cases involving business entities. A report prepared under the Ernst \& Young Program "Better Government", Warszawa 2005; T. Stawecki, W. Staśkiewicz, J. Winczorek, Between Polycentrism and fragmentation. The Impact of Constitutional Tribunal Rulings on the Polish Legal Order. A report prepared under the Ernst \& Young Program Better Government), Warszawa 2009, available at: http://www.ey.com/PL/en/Industries/Government---Public-Sector/Debate_Constitutional-Tribunal].

6 L. Morawski and M. Zirk-Sadowski already fifteen years ago explained formalism of Polish judiciary by a claim that the style of Polish decision-making is deductive, legalistic, and magisterial. See L. Morawski, M. Zirk-Sadowski, Precedent in Poland, in: Interpreting Precedent: A Comparative Study, edited by D.N. McCormick and R. S. Summers, Aldershot, 1997, p. 225. See also R. Mańko: The Culture of Private Law in Central Europe After Enlargement: A Polish Perspective, "European Law Journal" 2005/11/5, pp. 541-542.

7 On illusory and decorative references to international and European community standards as an example of practices described herein see M. Safjan, The Universalisation of Legal Interpretation, in: Interpretation of Law in the Global World: From Particularism to a Universal Approach, edited by J. Jemielniak, P. Mikłaszewicz, Heidelberg - Dordrecht - Berlin 2010, p. 122-123.

8 M. Zirk-Sadowski calls this practice a "soft Kelsenism" in his Soft Kelsenism versus Multicentrism: Some Remarks on Theoretical Foundations of European Law, in: Multicentrism as an Emerging Paradigm in Legal Theory, edited by M. Zirk-Sadowski, M. Golecki, B. Golecki, Frankfurt - Berlin - Oxford 2009, pp. 51ff. 
a consequence of permanence of the ways of understanding the law which are typical of the continental system (civil law), and which significantly differ from the common law legal culture, but also a consequence of the specific experience of a society which, for half a century and perhaps even longer, was under the influence of the legal culture of the east. The influence of these traditions has so far failed to break through the phenomenon of globalization and convergence of legal orders in the modern world.

\section{The electronic world of law}

Databases of legal texts began to emerge in Poland in 1993. They were both official databases created publicly and made available to the public by the state authorities, and private collections created and distributed commercially. Public databases are limited (while they are universally available on the Internet) because they contain one type of information: they either contain currently applicable statute law (for instance, the Online Legislative Acts created in the Sejm Chancellery in $1993^{9}$ ), or jurisprudence (for instance, the Constitutional Tribunal rulings available online since the end of the $1990 \mathrm{~s}^{10}$ ). In 2007 the Supreme Administrative Court ${ }^{11}$ made its past rulings available to the public online. Unfortunately, the rulings of the Supreme Court still remain available online only in a limited degree. ${ }^{12}$ Another collection that is of interest and of major importance in practice is the database of official interpretations of tax law, maintained by the Minister for Finance. All of these databases have been evaluated for several years. Invariably, since 2008, those performing research have repeatedly pointed out the need to introduce a uniform and centrally managed Polish jurisprudence website. ${ }^{13}$

The databases that are structured in the best way and contain all three modules (statute law, court rulings, including those of common courts, administrative courts and the Constitutional Tribunal, and sections of commentaries, academic articles, commentaries on rulings etc.) are, however, private databases. The first and most popular one is Lex, created by lawyers and IT specialists in Gdańsk at the beginning of the 1990s, and today owned by the publisher Wolters Kluwer Polska. ${ }^{14}$ Naturally, private collections are not universally available to the public and parties who apply the law. Originally, only law offices and law firms purchased them. It was not until later that they started to be used in courts and state administration. The turning point came in 2005-2006, when extra funds were designated for the functioning of Poland's judicature. It is significant that the use of legal databases by judges was only one element of a much broader

\footnotetext{
http://isap.sejm.gov.pl.

http://www.trybunal.gov.pl/orzecz/orzecz.html.

1 http://orzeczenia.nsa.gov.pl.

12 http://www.sn.pl/orzecznictwo/index.html.

13 See M. Gołębiowski, M. Kube, D. Sześciło, P. Rzymska: E-sądy po polsku. Badanie i ranking stron internetowych sądów okręgowych i apelacyjnych oraz Sądu Najwyższego i Trybunatu Konstytucyjnego, IV edycja [Eng. E-courts: Polish style. Analysis and ranking of web pages created for district courts and appeal courts as well as for the Supreme Court and the Constitutional Tribunal. Fourth edition], Warszawa, March 2012; available at: http://www.for.org.pl/pl/a/ 2120,e-sady-po-polsku-Badanie-i-ranking-stron-internetowych-sadow-okregowych-i-apelacyjnych-oraz-SaduNajwyzszego-i-Trybunalu-Konstytucyjnego.

14 Formally referred to as "System Informacji Prawnej LEX - SIP LEX". Other databases are: Lex Polonica, Legalis, etc. They are distributed commercially by big publishing houses: LexisNexis and C. H. Beck.
} 
scheme to computerize the judicial system. This also involved the process of expansion and computerization of public registers. It is a tendency to increase the scope of use of information technology in order to simplify judicial and administrative proceedings, and to make them less time consuming. ${ }^{15}$

Finally, Poland's accession to the European Union in 2004 had a major influence on the use of databases in Polish courts. This is because it was required that not only Polish legislation was harmonized with the EU standards, but above all that judges had the knowledge of the EU. This made direct access to the EU databases vital. The study and learning of the EU law by legal practitioners was also an important factor, as the EU law includes not only a description of the community institutions and information regarding material law, but also a philosophy of interpretation of the EU law.

\section{Legacy of the past}

As we have already noticed, electronic legal databases simultaneously support the practice of judicial formalism, as well as unrestricted discretion of courts. The explanation of both phenomena requires deeper reflection on the legal culture of Polish society and - more generally speaking - on the legacy of the past.

1. It is true that Poland is a country with a strong legal tradition, but not of continuity and steadiness in its legal system. The form of the legal system today goes back only to the beginning of twentieth century, when the period of more than one hundred years of non-existence of the Polish state ended - in 1918 - and there were five different legal systems in force on Polish territory. It was a huge achievement on the part of Polish lawyers that they unified these systems within the twenty years of the independent Republic of Poland, marking a return of the Polish legal system to the legal culture of the West. ${ }^{16}$

On the other hand, the socialist legal system - which existed in Poland from the end of the Second World War until 1989 - was characterized by a departure from the values and principles typical of Western European legal systems. The Polish legal system underwent structural transformation in the 1990s, when it took on the form it has today. This was a return to the Polish law as it existed before the Second World War (for example, the commercial code or bill of exchange legislation), introduction of norms for human and civil rights, and adoption in the Polish Constitution in 1989 of the doctrine of a "democratic state ruled by law"17 (having certain inspirations in the German concept of Rechtsstaat) ${ }^{18}$, which, in addition to shaping the political system, also significantly changed

15 See Ewolucja prawa polskiego pod wptywem technologii informatycznych. Elektroniczne aspekty wymiaru sprawiedliwości [Eng. Evolution of Polish law under the influence of information technologies. Electronic aspects of justice system], edited by J. Misztal-Konecka, G. Tylec, Lublin 2012.

16 On the process of unification of Polish laws during the inter-war period (1918-1939) see Handbook of Polish Law, edited by W. Dajczak, A. J. Szwarc, P. Wiliński, Warszawa - Bielsko-Biała 2011, pp. 40-41, 45-46, 403); Introduction to Polish Law, edited by S. Frankowski in co-operation with A. Bodnar, Kluwer Law International 2005, p. 37; M. Brzezinski, The Struggle for Constitutionalism in Poland, Basingstoke - London 1998, pp. 47-51; L. Górnicki, Prawo cywilne w pracach komisji kodyfikacyjnej Rzeczypospolitej Polskiej w latach 1919-1939 [Eng. Civil law in the Codification Committee of the Republic of Poland 1919-1939], Wrocław 2000, pp. 69ff.

17 L. Garlicki, The Principles of the System of Government in the Republic of Poland, in: The Principles of Basic Institutions of the System of Government in Poland, Warszawa 1999, pp. 56-57.

18 W. Staśkiewicz, a book review of B. Z. Tamanaha, On the Rule of Law. History, Politics, Theory, in: "Przegląd Sejmowy" 2006/2 p. 158. 
the form and applicability of the law. ${ }^{19}$ Additionally, harmonization with the EU law in the years 1994-2004 also had a huge influence on the shaping of the Polish legal system.

2. The identity of the modern practice of the functioning of the law in Poland is determined by both strong positivist tradition, as well as the experience of the second half of the twentieth century. It should be emphasized, however, that the extensive scope of discretionary power of contemporary Polish judges is not a continuation of the roles of judges from the era of communism. ${ }^{20}$ In the case of Poland, the practice was different to that of other communist countries. ${ }^{21}$ In order to understand this, one should be aware that the application of the law in the era of the People's Republic of Poland was based, to a much greater extent than in other countries, on a syllogistic model of law enforcement, rather than legal voluntarism or even nihilism, which was typical of the Soviet Union and other socialist countries. In most communist bloc countries, the application of the law was subordinated to a much greater extent than in Poland to the guidelines of the Communist Party, "socialist / people's / proletarian morality", the standards of the "principles of social coexistence", class interests as identified by the official ideology, the requirements of fully nationalized communist economy, as well as political and police institutions of authority.

The reasons for Polish lawyers stubbornly hanging on to formalism as a selected policy of applying the law ${ }^{22}$ and a model which was typical of Western European legal culture of the nineteenth and the first half of the twentieth century, were the attempts in Poland to build a defense against the idea of communist ("socialist") law, which, instead of the provisions of positive law, relied to a much greater extent on the implementation of ideological standards (mentioned above). Such an understanding of the law also supported and expressed the ideology of "socialist legality" and - although it sounds like a contradiction - "socialist legal state". Even so, this concept was far from the traditional liberal idea of the rule of law and the idea of Rechtsstaat formed in Central Europe. In fact, legal practice during the communist regime in Poland may be qualified as the concept of the "rule by law" rather than the "rule of law". ${ }^{23}$

3. Resistance to legal voluntarism in the communist Poland was supported by at least two types of reasons: (1) the ethos of judges brought up by the tutors who were ideologically educated in the era of the independent Poland (1918-1939), and

19 See J. Přıbán, Constitutional Symbolism and Political (Dis) continuity: Legal Rationality and Its Integrative Function in Post-communist Transformations, in: Rethinking the Role of Law after Communism, edited by A. Czarnota, M. Krygier, W. Sadurski, Budapest - New York 2005, pp. $295 \mathrm{ff}$.

20 See E. Łetowska, Courts and Tribunals under the Constitution of Poland, in: Constitutional Essays, edited by M. Wyrzykowski, Warszawa 1999, pp. 192-195 (article published also in "Saint Louis - Warszawa Transatlantic Law Journal" 1997, pp. 69ff.).

21 For details see A. Fijałkowski, The Judiciary's Struggle towards the Rule of Law in Poland, in: The Rule of law in Central Europe. The Recostruction of Legality, Constitutionalism and Civil Society in the Post-Communist Countries, edited by J. Přıbán̆, J. Young, Dartmouth 1999, pp. 242ff.

22 This argument contradicts a well known thesis of Ch. Perelman that "A less formalistic vision of the law is rising in the legal positivism". Ch. Perelman, Justice, Law, Argument. Essays on Moral and Legal Reasoning. Dordrecht, Boston, p. 124.

23 On differences see B.Z. Tamanaha, On the Rule of Law. History, Politics, Theory, Cambridge 2004, pp. 79, 82-84. See also T. Stawecki, Independence of the legal professions and the rule of law in post-communist society, in: Niezależność sadownictwa $i$ zawodów prawniczych jako fundamenty państwa prawa. Wyzwania wspótczesności / Independence of the Judiciary and Legal Profession as Foundations of the Rule of Law. Contemporary Challenges, edited by T. Wardyński, M. Niziołek, Warszawa 2009, pp. 348-349. 
(2) the consistently preached philosophy of the law referring to legal positivism, the fullest expression of which was, among others, the achievements of an outstanding representative of the Polish theory of law - J. Wróblewski. Some other circumstances also mattered. The experience of the application of law during the era of the Stalinist terror in Poland certainly had a disastrous effect on the rule of law. This experience was a warning for lawyers from 1956 onwards. The impact of legal positivism adopted in the version of socialist normativism by A.J. Wyszyński, which from 1936 was an official legal doctrine in the communist states, was also complicated. It glorified the state and the incumbent powers, but - as it is rarely noted - legal positivism not only legitimized communism through an extremely instrumental and etatistic concept of the law, but was also a weapon used by judges and citizens against the authorities to emphasize the need for strict compliance with the letter of the law and avoidance of reference to "socialist values" and general ("rubber") clauses incorporated into the texts of statutes. Legalism in the form of application of legal syllogism and avoidance of rulings that made reference to socialist values or socialist morality was a kind of line of defense of civil rights. As J. Wróblewski believed, social homeostasis may be reached if balance is achieved between the instrumental role of law, rationality of law-making processes, and restrictions in the process of application of law by judges. ${ }^{24}$

This assertion is neither a defense of the former regime nor an attempt to glorify the judges or academics of this period; we leave the judgment on this phenomenon to history. ${ }^{25}$ However, the fact that Polish judges and legal theorists were strongly attached to the letter of the law (without even having a democratic pedigree or strong political legitimacy) is of importance to our subject. Such attachment had both positive and negative consequences. It gave rise, inter alia, to far-reaching formalism in the interpretation of the provisions of the law, which largely arose from fear of being guided in the judiciary by the current political views or the idea of "people's justice" or the ideology of the ruling party.

4. Furthermore, the legal formalism of Polish judges was also reflected in the developing of idealizing assumptions about rationality of legislation ("lawgiver's rationality", "law-making rationality"), key condition of interpretation of law treated as a closed ("complete") and consistent system of rules (standards), as well as justification of law-making procedures as the search for optimal and the most effective solutions. ${ }^{26}$ The idea of rationality of legislation was identified with the actual irrationality of the Polish legislature and deep, sometimes blatant, injustice, and serious inefficiency of legal regulations in social life. Nobody (other than dissidents, who did not apply the law) dared challenge the ideological theses of the rationality of the socialist legislature's actions in the process of applying the law.

24 See for example J. Wróblewski, Law as an Instrument of Social Homeostasis, "Archiv fuer Rechts- und Sozialphilosophie" 1981/1; J. Wróblewski, A Model of Rational Law-Making, "Archiv für Rechts- und Sozialphilosophie" 1979/2 pp. 187ff.; J. Wróblewski, Legal Syllogism and Rationality of Judicial Decision, "Rechtstheorie" 1974/1, pp. 33ff.; J. Wróblewski, Principles, Values and Rules in Legal Decision-Making and the Dimensions of Legal Rationality, "Ratio Juris" 1990/3/1, pp. 100-117.

25 More details A. Czarnota, Between Nemesis and Justitia: Dealing with the Past as a Constitutional Process, in: Rethinking the Role of Law..., pp. $123 \mathrm{ff}$.

26 On the origin of the concept of rational lawgiver see M. Smolak, Contemporary Polish Theory and Philosophy of Law, in: Handbook of Polish Law ..., pp. 79-80. 
The source of the conviction that the idea of law-making rationality is or at least may be implemented in legal and political practice was a belief, on the one hand, in a technocratic, modernist model of legal policies, and on the other hand, in the absoluteness of the innovative functions of the law. To a large extent, this was also a reflection of the assumptions of a dogmatic version of legal positivism. This assertion, which by definition was not subjected to empirical verification, became the cornerstone of law making in contemporary Poland. Its consequence is legitimization of every parliamentary decision, even though its consequences are far from expected, and it is a source of serious dysfunctions of the regulations which were created. ${ }^{27}$

The idea of lawgiver's rationality also finds its expression in the processes of interpretation of law. Lawyers refer to the so-called preparatory work, especially justifications of bills which are available through the websites of the Polish parliament. In this sense, legal databases support a certain kind of intentionalism in the process of applying the law. However, this is not the best criterion for interpreting legal texts because: (a) justifications of bills are frequently an expression of wishful thinking instead of a reliable analysis, (b) the previously mentioned idealism, involving acceptance of the irrefutable assumption of rationality of law-making, also has a negative impact on the process of applying the law.

5. The phenomena described: historical background, law-making instrumentalism, formalism in the application of the law and the idealism of legal thinking influenced the practice of creating and applying Polish law after the political transformations in 1989. This is a typical influence of historical foundations. Let us remember that, in the case of Poland, the previous "socialist" system of law was not rejected after the "Solidarity" leaders came to power and after the role of the communist formations was reduced to a minority opposition, but an evolutionary model was chosen for its transformation through amendments and adjustments in the process of applying the law. ${ }^{28}$ No fundamental replacement of judges took place after 1989. Many statutes passed in the era of the People's Republic of Poland are still in force, especially the codes. Additionally, many judges educated in faculties of law and developed in the practices of the 1970s and 1980 s still adjudicate.

6. Regardless of the fundamental circumstances of a social or political nature, many formal premises directly related to the law and legal practice setting out the principles and the limits of interpretation and application of the law have changed after 1989. Six of the most important phenomena deserve to be pointed out.

First, the so-called guidelines of the Supreme Court ("wytyczne wymiaru sprawiedliwości” - official and binding recommendations on how to interpret and apply specific regulations) were rejected in 1989 as being incompatible with the constitu-

27 The concept of "functions" and "dysfunctions" was brought to the legal theory through sociology of law. See for example A. Podgórecki, Law and Society, London 1974, p. 30; R.B.M. Cotterrell, Law, Culture and Society: Legal Ideas in the Mirror of Social Theory, Aldershot 2006, p. 113; A. Porat, Enforcing Contracts in Dysfunctional Legal Systems: The Close Relationship between Public and Private Orders: A Reply to McMillan and Woodruff, "Michigan Law Review" 98/8, Symposium: Empirical Research in Commercial Transactions (Aug. 2000), pp. 2459-2480.

28 D. Piana, Judicial Accountabilities in New Europe. From Rule of Law to Quality of Justice, Aldershot 2010, p. 98. 
tional principle of the independence of judges. Previously, they constituted the official basis of interpretation for Polish courts, and their knowledge was mandatory. They also served to consolidate the interpretations made by the common courts. However, a small number of guidelines reduced their practical significance.

Since the early 1990s, Polish jurisprudence has ceased to be subjected to review through binding guidelines of the Supreme Court. This had both positive (increase in the autonomy of the courts) and negative consequences. Years later, it transpired that regionalisation of the interpretation of the law had arisen - courts rule differently in the same cases in different parts of the country, which is a serious problem.

All of this together was related to the unclear status of jurisprudence in the system of law. In the light of the constitution of the Republic of Poland, court judgments are formally not a source of law (the bodies applying the law cannot create it), whereas, they are a subject of references and reasonably numerous citations in the process of interpreting the law. Similarly, the role of jurisprudence is not as clearly defined as in the case of common law, but it is difficult to deny it actual significance. ${ }^{29}$ In the case of Poland, a certain role is played solely by the principles written into the so-called "Book of legal principles" of the Supreme Court, as well as the Constitutional Tribunal jurisprudence. The Constitution of 1997, however, granted neither the Supreme Court nor the Constitutional Tribunal an authority to issue formally and universally binding interpretations of law, as were known under the Constitution of 1952 (as amended in 1985).

Second, material principles of the system of law adopted in the communist era were rejected. This peculiar "decapitation" of the Polish system of law entailed a normative void, which was even greater because the new constitution was passed as late as in 1997. After all, the fact that the principles of the new constitution were enacted did not, at least, prejudge their application in public life. In turn, actual lack of ideology, or even enigma of the political parties as to political programs, and far reaching visions of development of the society, led to divergent political interpretations of the content of the provisions of the constitution.

Of course, Poland's accession to the European Union and harmonization of Polish law with the Community law bolstered the Polish system of law with a set of new principles; but even these were not automatically accepted in practice and legal theory.

Third, the number of amendments to the existing provisions of the law has sharply increased. This spontaneous phenomenon, together with the process of harmonization of Polish law to the standards of the acquis communautaire of the European Union, has destroyed the coherence of legal institutions and leads to actual decodification of the Polish system of law. In the near future, the consequence of this phenomenon will be far-reaching pluralisation of the legal doctrine reflected in a rapidly increasing number of commentaries in individual branches of the law, with a simultaneous decline in the quality of these commentaries. In the era of communism, the provisions of the Civil and Penal Codes were changed very rarely, while the commentaries on each of the Codes were almost of an official nature. Just as all publications, they were censored, and the Polish Academy of Sciences additionally lent its name to them. Competitive commentaries were nearly unthinkable. The official commentaries con-

\footnotetext{
29 For the analysis of an increasing role of courts in the second half of the twentieth century see M. J. Golecki, Między pewnością a efektywnością. Marginalizm instytucjonalny wobec prawotwórczego stosowania prawa [Eng. Between certainty and efficiency. Institutional marginalism and judicial lawmaking], Warszawa 2011, pp. 25ff.
} 
tained interpretations which were monopolized by the lawyers who had the recognition of the "socialist elite."

Today, the who publishes a commentary on changing provisions of the law is unimportant; of importance is how fast he or she does it, in particular in reference to the latest amendments to the binding laws - authority is of secondary importance in this case. Every bigger legal publishing house sets itself an objective of issuing its own commentaries as quickly as possible, and subsequently to incorporate them to particular databases that it distributes. Currently, there are perhaps several dozens of publications on the most important branches of law. The commentaries are also not subject to detailed discussions in academic circles and among practicing lawyers. With ever-new faculties of law being established, accelerated promotion paths of academic staff and the failure to start work on the unification of the Polish system of law, it is difficult to consider the authority of the commentaries published. As a result, almost every quote from any commentary can constitute an argument not only in expert legal opinions, but also in the reasons (formal justifications) of judicial decisions.

Fourth, a change of the economic system into a market system has become a challenge for courts. ${ }^{30}$ Previously unknown economic institutions, which are governed by their own logic, clashed with both the mentality of judges formed under a system of dominating state ownership and the provisions of the law which were adapted to different institutions. The intensity of systemic transformations could not be immediately and directly translated into new provisions of the law implementing the requirements of the system. The task of adjusting the law to the new economic terms and conditions was assigned not only to the parliament, but also to the community of judges. A hidden result of those new phenomena was a rapid extension of the interpretative freedom of judges, as well as various applications of judicial activism. ${ }^{31}$ It should be remembered that the interpreter's knowledge of at least fundamental laws and mechanisms of the market is of key importance in the interpretations of the law in economic matters, while lawyers are not a group which is highly familiar with economics. ${ }^{32}$

Fifth, a permanently increasing number of new laws and legal acts essentially had to lead to diverse interpretations of the law. Sloppiness and haste in the process of formulating legal texts, breaking the rules of legislative techniques (and frequently common sense), and treatment of the law as a spectacular public relations tool were, sadly, commonplace. This led to pointless disputes about linguistic meaning of legal texts, and to numerous cases of ignoring the purposes of legislation (rationes legis). Searching for the "true" will of the legislating Sovereign often proved to be a Sisyphean task, which can be - unfortunately - easily seen in the jurisprudence of the Constitutional Tribunal recognizing laws as unconstitutional. ${ }^{33}$

30 On the role of courts in the process of economic transformation see X.J. Paparrigopoulos, The Role of Courts in Crisis and Transition Periods: Courts as Image Makers, in: The Role of Courts in Society, edited by S. Shetreet, Dordrecht 1988, pp. 72ff. See also T. Stawecki, Sędziowie w procesie reformowania prawa [Eng. Judges in the process of reforming of legal system], in: Analiza ekonomiczna w zastosowaniach praktycznych [Eng. Economic analysis in practical application], edited by J. Stelmach, M. Soniewicka, Warszawa 2007, pp. 167-190.

31 L. Morawski, Zasada trójpodziału władzy. Trybunat Konstytucyjny i aktywizm sędziowski [Eng. The Tripartite Division of Powers Principle. The Constitutional Tribunal and Judicial Activism, "Przegląd Sejmowy" 2009/4, pp. 59-74.

32 This is also related to the ways of promoting judges. Lawyers with significant experience gained in prosecution or the Bar are selected to be a part of this group. The principle is that young graduates of faculties of law become judges after special two-year additional training (the so-called judge training) and an examination. However, none of them could demonstrate significant experience in legal practice.

33 See T. Stawecki, W. Staśkiewicz, J. Winczorek, Between Polycentrism and fragmentation ..., pp. $24,71$. 
Sixth, the situation has been further exacerbated by continuous revisions of the codes and the "instability" of legal institutions which were established in the new social conditions. Numerous amendments to the codes have seriously altered the functioning of the "traditional" legal institutions, whose pedigree sometimes dates back to the times of Ancient Rome. ${ }^{34}$ Vastness of the standards requires not so much using the traditional methods and directives for the interpretation of the law which are characteristic of Ronald Dworkin's rules, but rather referring to principles as standards subject to balancing, as well as to political objectives (policies) reconstructed in a reliable manner. ${ }^{35}$ Much more sophisticated measures and tools are required also in case of complex conflicts of laws, which arise between the provisions of the national law and the standards of the EU law and other forms of "non-state laws" ${ }^{36}$ It should be remembered that the policies of the international (supranational) organizations in the era of globalization are not always consistent with a current policy of a given state. At the same time, the role of particular procedures and technical norms imposed by global institutions is constantly growing.

In this state of affairs, within a short space of time, Polish judiciary was faced with challenges that other countries had been solving for generations. The main problem turned out to be a dilemma of how the formalistic positivist model of law (indeed functionally connected with the Rechtsstaat doctrine), together with its fundamental instrument in the application of law - legal syllogism - could be reconciled with new demands of the market, the public and democracy, requiring a reference to values, legal principles and norms of other normative systems.

\section{Legal databases and a shift in the paradigm of judicial interpretation and practice in decision-making}

1. The introduction of legal databases was a very important change in Polish judicial practice. Up to the 1990s, most cases were of a routine and relatively straightforward nature. For the last twenty years, the judicial practice has significantly changed. On the one hand, it has been a consequence of implementation of new forms of regulation and permanent changes to the binding laws. If we realize how often and how quickly the existing laws are amended and that an average Polish statute is modified even twenty times ${ }^{37}$, we are able to understand that the use of journal of laws in a traditional paper form is simply impossible.

34 Arguments in defense of codes as normative acts are sometimes raised in the literature. See W. Staśkiewicz, Prawo jako narzędzie polityki państwa okresu przemian (przeszłość wobec przyszłości) [Eng. Law as an instrument of public policies in transition countries (past versus future)], in: Prawo a polityka [Eng. Law and politics], edited by M. Zubik, Warszawa 2007, p. 73.

35 A similar opinion is expressed by the authors who appeal to introduce the discourse ethics to our legal practice. See for example B. Wojciechowski, Discourse Ethics as a Basis of the Application of Law, in: Interpretation of Law in the Global World..., pp. 64ff.

36 One of the key ideas was the concept of "multicentrism" proposed and developed by the judge of the Constitutional Tribunal, E. Łętowska. See E. Lętowska, Multi-centricity of the Contemporary System of Law and its Consequences, "The Polish Foreign Affairs Digest” 2005/15/2 (available also in the Internet). Original sources: E. Lętowska, Multicentryczność wspótczesnego systemu prawa i jej konsekwencje [Eng. Multi-centricity of the contemporary system of law and its consequences], "Państwo i Prawo" 2005/4, pp. 3-11; E. Łętowska, Między Scylla i Charybda - sędzia polski między Strasburgiem i Luksemburgiem [Eng. Between Skylla and Charybdis - Polish judge between Strasbourg and Luxembourg], "Europejski Przegląd Sądowy" 2005/1, pp. 3-8. See also Multicentrism as an Emerging Paradigm in Legal Theory...

37 The leader - the law on personal income tax - was amended more than two hundred times. 
Only electronic legal databases revised and updated on everyday basis are able to provide the end users with actual texts of binding laws. Judges would be unable to track journals of laws issued in their traditional form to see all important changes ensuing in the content of the law. This is the basis of the previously mentioned "necessity thesis".

On the other hand, the decline in the importance of the codes in judicial practice and new social functions of legal institutions have completed the process of internal differentiation of the system of law. In this situation, the use of databases and good knowledge of judicial decisions have become necessary. If material principles of the system of law are not clear enough as a result of "decapitation" of the Polish system of law, then previous decisions of courts and tribunals are not the sources of precise rules, but rather reference points in the process of judicial navigation.

2. The above obviously does not mean that the introduction of legal databases solved the problem of lawyers' knowledge of the law. The content of individual databases available on the market and quality of databases are, however, differentiated. This is why some of them do not contain all provisions of changing transitional regulations, harmonization regulations etc. Therefore, practice shows that the notion of the system of law which was adopted by the authors of individual databases is somewhat different in each case, and the judge needs to reach a high level of understanding of such a system of law in order not to make a mistake.

In addition, the access to court decisions and commentaries available through electronic databases has had a significant impact on the methods of interpreting the law and the method of justifying court judgments. It should be noted that we have been dealing with two models of court's decision and justification of judicial verdicts. In the first one - today more historical - judges used to prepare lengthy justifications of courts, including numerous references to judgments so as to present all possible arguments in those justifications. The second model, noticeable in the last few years, has been the return to shorter, but more precise legal justifications which do not concentrate on what is available to everyone, but on the most important aspects. A judge no longer has to prove that he or she has examined all important sources. He or she would not be able to do that. It is recognized as a sufficient argument to cite other judicial decisions that illustrate a satisfactory decision in a given case. In the civil law system, it is enough to argue that the general direction of decision-making is correct.

Reaching out for court judgments certainly popularized the "argument with authority" (Latin: argumentum ex auctoritate). Instead of referring to the substance of the regulation (rules of positive law), in order to demonstrate validity of its own interpretation of the law, a court refers to rulings of higher courts, especially the Supreme Court, in accordance with the interpretation adopted by the court. In this way, the court suggests that its reasoning applied in a given ruling has been previously confirmed in decisions (preferably numerous) of the Supreme Court. The validity and correctness of the interpretation is justified not only by the authority of the adjudicating court, but also the authority of higher courts. This is also understood as a kind of "objectivization" of jurisprudence. This is because judges state that it is not only their own subjective interpretation of laws, 
but also the interpretation which is accepted by higher courts, especially the $\mathrm{Su}-$ preme Court.

3. The use of a legal database often means also that when choosing among various methods of interpreting the law, judges eagerly give precedence to the literal interpretation. It can be understood to some extent. Lawyers, including judges, are surrounded by texts, and it seems to be so natural to adhere to legal formalism as a strategy of professional conduct. Judges treat legal concepts as if their substance were complete and crystal-clear. They deny that the link between a legal text and a resolution of a case - in particular a hard one - is remote, and that the solution may be indeterminate and it requires moral, political or economic considerations. They also do not acknowledge that rules are vague, uncertain and conflicting, and that there is often a choice of several rules that might apply in a case. ${ }^{38}$ If a text of legal provisions is so easily available to everyone (thanks to legal databases), and other possible reasons or contexts seem to be much less certain, there have to be really strong reasons to depart from the legal text. International research studies show that such reasons are sometimes found in the constitution or in the EU law, although in majority of cases (easy cases) or in routine judicial practice, fidelity to the text is regarded as an implementation of the rule of law (Rechtsstaat) principle.

The position that the language context is the most important and, in principle, should not be undermined by other contexts or arguments can be found in many rulings of the Supreme Court. It is recognized - even if criticized by many representatives of the theory of law or philosophy of law rejecting the so-called claritas doctrines and principles - that what is clear should not be subjected to special interpretive treatment (clara non sunt interpretanda). ${ }^{39}$

The strategy of "textualism", as developed in Central Europe, and priority of literal interpretation are also justified by a variety of practical arguments. We have previously mentioned the phenomenon of "decapitation" of the system of law involving blurring of the basic axiological assumptions of this system. Therefore, if a court is unable to reconstruct the objectives to which it should aim or the values which it should serve it willingly refers to the wording of legal acts as a final argument. Since it easily finds the wording of applicable rules in an electronic database, while other alternative ways of adjudication give rise to doubts, the text seems to be the safest source of the knowledge of the law. As in Protestant biblical hermeneutics: sola scriptura, only the text of the Bible can be a source of authoritative truth.

The primacy of textualism is paradoxically reinforced by the abovementioned multiplicity and weakness of commentaries to statutes, or the lack of commen-

38 M. Matczak, M. Bencze, Z. Kühn, Constitutions, EU Law and Judicial Strategies in the Czech Republic, Hungary and Poland, "Journal of Public Policy" 30/1, p. 87; M. Matczak, Summa Iniuria. O btędzie formalizmu w procesie stosowania prawa [Eng. Summa iniuria. Formalism as an erroneous way of applying laws], Warszawa 2007, p. 114.

39 Arguments against the presumption of clarity of a legal text were raised, among others, in the writings of Ch. Perelman, who was claiming that the opinion on unnecessary character of interpretation was abandoned already in the French Civil Code of 1804. See Ch. Perelman, Justice, Law, Argument..., pp. 131-132. Also Polish contemporary legal theory argues that in the process of applying the law, it is always necessary to interpret legal texts (omnia sunt interpretanda) and all relevant interpretive contexts should be used, if only to confirm the correctness of the literal interpretation. See M. Smolak, Contemporary Polish Theory and Philosophy of Law, in: Handbook of Polish Law ..., pp. 77-78. 
taries to many specific statutes. In the case of new legislation, there are often no such commentaries. Dozens of statutes have been enacted or substantially amended in Poland in the last five years, to harmonize the Polish legal order with the standards of the EU law. Many others have been introduced or modified to respond to the new economic and social phenomena. In this respect, the doctrine of law did not have time to develop a though-out position. Therefore, if there are no commentaries yet, lawyers and judges refer to the texts when interpreting specific provisions of the law. There are no other good sources, while the text is easy to find in electronic legal databases.

4. The search for court judgments, not through ratio decidendi contained in them, but because they are included under a specific provision of the law, means that even highly developing jurisprudence of the courts in Poland does not fully fit to the main models of case law. This is because in the system of case law it is important to refer to the facts of the case. It stems from the fact that a case in which the relevant facts are identical or at least very similar to the facts in the case pending settlement constitutes a precedent. Polish practice is sometimes referred to as "de facto precedents", although some representatives of the doctrine question this term because it suggests a binding nature of court judgments, which, according to the Polish constitution, is still very doubtful. ${ }^{40}$

Meanwhile, in the case of the jurisprudence of Polish courts, which are accustomed to using legal databases, these facts are almost overlooked. Of importance to the reader is the circumstance that a given ruling contains an interpretation of a specific regulation, which is to be used in a new case and which was also interpreted in a previous court ruling. Therefore, the relationship between the judgments and the individual regulations and not the relationship between the ratio decidendi and specific facts is important. Thus, we claim that the concept of de facto precedents, appearing in the Polish theory of the law as not formally binding sources of the law, is unfounded. However, it can be claimed that such development of the law from a general principle contained in a statute to detailed rules and standards expressed in jurisprudence is also a significant change in the system of law. Our "thesis of relevance" is well confirmed here.

5. The use of databases had a noticeable impact on reaching out for systemic arguments, namely those referring to the relationship between various rules and principles of the law, and sometimes to the values of particular importance in given fields of law. This is not only a result of the fact that judges had better knowledge of various rules and changes in the laws in force in a certain area. This is because databases not only contain consolidated texts of applicable legal acts, but also specify when and by which particular statute a specific regulation was changed. Therefore, a judge can check whether the regulations in one version or another applied to the period in which the conduct of the parties which was relevant to a given case took place. The reference to such circumstances is of the nature of the so-called systemic interpretation.

40 B. Wojciechowski, Dyskrecjonalność sędziowska. Studium teoretycznoprawne [Eng. Judicial discretion. Theoretical study], Toruń 2004, p. 214; T. Stawecki, Precedens w polskim porządku prawnym. Pojęcie $i$ wnioski de lege ferenda [Eng. Precedent in Polish legal order. The concept and recommendations de lege ferenda] in: Precedens $w$ polskim systemie prawa [Eng. Precedent in Polish legal order], edited by A. Śledzińska-Simon, M. Wyrzykowski, Warszawa 2010, pp. 59ff. 
Thinking about the system of law through electronic databases can lead to simplifications. First of all, such experience can strengthen lawyers' belief that the law is everything that is in vast electronic databases and vice versa: if a norm is not mentioned in a legal database, this means that it is not a legal norm. This means, as we have mentioned, reinforcement of the lawyers' belief in primitive legal positivism. Simultaneously, a belief in universality of electronic databases means that a lawyer more easily gives up searching for fundamental principles in the sense of the Dworkin's "principles". This is because databases are becoming a modern instrument for conducting the "test of pedigree" of legal rules and principles.

\section{A dysfunctional role of legal databases for the processes of interpretation}

1. Judges' use of rulings of other courts, which are available by means of electronic legal databases, has also a negative side. This is because it should be remembered that court rulings in legal databases are structured according to the order of provisions of the statutes on the basis of which the judgments were passed. Therefore, when looking for judgments, a judge first finds a basic provision of the statute and then reads the ruling, which was classified by the authors of the database and not by other judges as being related to this provision. This is obviously a significant simplification because, in fact, the authors of the database decide on the method of interpreting the law by courts instead of the courts themselves publishing their judgments, as it was the case in the past.

Therefore, the practice of searching for judgments by looking for a leading provision leads to the conclusion that we are dealing with an interpretation which is somewhat reminiscent of the early Middle Age concept of "determinatio." 41 This idea arose as a response to the question of what conclusions should be drawn from the Ten Commandments received by Moses on Mount Sinai, or, in other words, how should a rule which will be applicable to a very specific, not typical case be derived from a very general rule such as "Thou shalt not kill." A similar mechanism exists in the process of using electronic legal databases. The wording of statutes and other acts of positive law contain general rules or principles of conduct. However, these rules are subject to detailed specification (determination) in the judgments of courts chosen by virtue of leading regulations and thereby contained in the database.

However, that practice of selecting judgments enables judges to choose the ones which will be raised in the judgments passed in a reasonably unhampered manner. In this way, a court's practice actually justifies highly extensive discretionary power of courts. Recalling the previously discussed formalism and idealism in the application of the law, we can understand what the internal conflict of the functions of databases is based on. On the one hand, formalism suggests that judges keep as close as possible to the set text of statutes (textualism), and

${ }^{41}$ The concept of "determinatio" is still discussed in the philosophy of law and legal theory. See J. Finnis, Philosophy of law. Collected Essays: Volume IV, Oxford 2011, pp. 123, 128, 131-132 and other; N. MacCormick, Rhetoric and the Rule of Law. A theory of Legal Reasoning, Oxford 2005, pp. 10-11; N. MacCormick, Institutions of Law. An Essay in Legal Theory, Oxford 2007, pp. 248, 254-255. 
on the other hand, they enjoy considerable freedom and discretionary power. This is the basis of the third thesis of our paper (the thesis of an internal conflict in the functions of a database).

Making reference to earlier decisions very often serves as a mere "fig leaf." When adjudicating and citing previous rulings of the Supreme Court, a judge is guided by opportunistic thinking, so that his or her decision is not overruled. Therefore, he or she expects that it will not be overruled if he or she makes a reference to several or more rulings previously passed by the Supreme Court in support of his or her interpretive thesis. However, this is not a real authoritative argument, or development of the system of law, but purely a reasonably primitive rhetorical operation. We can observe a practice of multiple repetitions of specific case references in successive judgments with the use of a "copy and paste" method.

2. Given very frequent references to earlier rulings of the Supreme Court and the Supreme Administrative Court, formulation and specification of "lines of judgment" has become a common practice for higher courts. This involves citing three up to five different judgments, additionally recognized (rightly or wrongly, it does not matter) as being compatible or at least consistent with each other. The purpose of this is to emphasize that the judgmental policy of a given court is constant and that, in this respect, the court reinforces the principle of certainty of the law. However, such a solution has its disadvantages:

a) efforts to build lines of judgment obviously lead to judicial conservatism and petrification of the legal order. In a situation where economic and social reality changes extremely and unusually quickly, an attempt to maintain a permanent line of judgment often leads to the charge of judgmental anachronism and its unacceptable formalism. It also undermines belief in the certainty of the law as a protected value;

b) searching for lines of judgment means concentrating on the place where the provision of the law is interpreted in the whole of the legal order. It discourages reaching out for functional (pragmatic) arguments;

c) arguments of lines of judgment sometimes prove to be illusory. If various compositions of the Polish Supreme Court (three-person or seven-person) adjudicate, we often encounter a situation where, depending on the adjudicating panel, various interpretations of the provisions of the law are adopted. Therefore, various court rulings are passed. In this sense, the argument of the stability of adjudication is unreliable. Courts which later refer to such lines of judgment have a comfortable position because they are in the role of a person who "picks the most beautiful cherries from the basket." This is because the adjudicating court chooses the rulings from the rich legacy of the Supreme Court and the Supreme Administrative Court which suit it in its decision, and completely arbitrarily ignores the rulings which do not suit its decision. This is yet another example of the abovementioned extensive discretionary power of judge-interpreters.

3. It could be said that electronic legal databases unduly simplify a legal system. As the law is made up only of those principles that can be searched for electronically, the distinction between the statutes and the Constitution becomes less 
clearly defined. Therefore, lawyers have a tendency to treat the Constitution as a set of rules, and not principles that require constant balancing.

In Polish conditions determining whether a given provision is in line with the Constitution is the most difficult and most controversial interpretation. This type of test is fundamental to a democratic state ruled by law. The controversy regards the boundaries of interpretation. In this case electronic databases provide a full range of material (rulings issued by the Constitutional Tribunal are prepared diligently, and furthermore, they are universally available). Depending on the legal culture represented, experts limit themselves either to an analysis of the provisions and the rules contained within them, or perceive the provisions as containing also legal principles, values, or political aims. In an extreme example - the dogmatic approach - even the Constitution will be perceived as a set of rules, and the provisions within it will be treated literally. In the case of interpretation of this kind in practice, we encounter all problems of contemporary legal philosophy, legal formalism, disputes over boundaries of interpretation of law, different models of constitutional courts' adjudication, and justification of specific decisions referring to political goals and public morality. As it is well known, this problem has been solved in the US by making a distinction between two types of legal interpretation: constitutional interpretation and statutory interpretation. As Lech Morawski has commented " $(\ldots)$ constitutional interpretation, especially of fundamental issues, is primarily an interpretation of standards, and hence interpretation of the principles, aims, ideals and values on which the constitutional order is based, while interpretation of statutes for the most part concerns an interpretation of ordinary rules". ${ }^{42}$ As an incidental note we also have a Hungarian variation of constitutional interpretation, in which rulings of the Hungarian Constitutional Tribunal have created so many rules and principles not provided for in the wording of the Constitution, and treating them as an inherent part of the Constitution, that this has given rise to the well-known concept of the "invisible constitution". ${ }^{43}$ The Polish model demonstrates lack of acceptance - both on the part of politicians and some judges - of acknowledgement of acquis constitutionnel, i.e. the rulings issued by the Constitutional Tribunal, as an element of the Constitution. ${ }^{44}$ Apart from political aspects of this debate, this has a direct influence on the dominant legal reasoning. While it is true that lawyers cite the Constitutional Tribunal rulings in their opinions, their reasoning is usually limited to formal aspect of legal reasoning, and moreover - as our research has shown - it is ornamental in character, and amounts to often random invocation of sections of a text issued by a constitutional court explaining the reasons for a ruling.

42 L. Morawski, Czy sądy mogą angażować się politycznie? [Eng. Can courts be active politically?], "Państwo i Prawo" 2006/3, p. 17. See also L. Morawski, Positivist or Non-Positivist Rule of Law? Polish Experience of a General Dilemma, in: The Rule of Law after Communism. Problems and Prospects in East-Central Europe, edited by. A. Krygier, A. Czarnota, Aldershot 1999, pp. 39ff.; A. Barak, The Judge in a Democracy..., pp. $130 \mathrm{ff}$.

43 L. Morawski, Czy sądy mogą.., p. 7.

44 On the models of constitutional courts and their decision-making practice see W. Sadurski, Legitimacy and Reasons of Constitutional Review after Communism, in: Constitutional Justice, East and West. Democratic Legitimacy and Constitutional Courts in Post-Communist Europe in a Comparative Perspective, edited by W. Sadurski, Hague-London-New York 2002, pp. 172ff.; L. Garlicki, The Experience of the Polish Constitutional Court..., pp. $265 \mathrm{ff}$. 


\section{Between the exegesis and "hybrid interpretation of the law"}

A reflection on the influence of the practice of judges taking advantage of electronic databases suggests that traditional theories of interpretation neither describe the actual methods of interpreting the law in Poland nor they design such methods. In the process of adjudicating, Polish courts simultaneously use many types of interpretation, but it is the formalistic approach that dominates. A more correct method of describing the interpretive practice appears to distinguish the following types:

A. Model of interpretation as a closed process (sometimes also called the exegesis model $\left.{ }^{45}\right)$. It is analogous to the hierarchically built and closed model of the system of law (as for example in the case of H. Kelsen). A result of the interpretation is determined exclusively by a legal text, to which a meaning is attributed $a$ priori. In this case, the most important role of legal databases is to provide the current text of applicable regulations. This does not mean that other types of information contained in databases are completely useless, but, even so, the wording of the regulations is determined primarily on the basis of semantic analysis. With this type of interpretation, even vague and indefinite phrases are treated as if they were assigned a permanent legal content.

B. Model of interpretation as an open process (sometimes also called the hermeneutic model of interpretation of a legal text, or the theory of discretionary hermeneutics). In this case, the meaning of a text is determined by the needs and expectations of the citizens and the social system. This concept of interpretation is typical of "open systems of law". It does not refer to some mythical "living law". Its grounds are the rules actually functioning in a society. Aharon Barak noticed: "The judge has an important role in the legislative project: The judge interprets statutes. Statutes cannot be applied unless they are interpreted. The judge may give a statute a new meaning, a dynamic meaning, that seeks to bridge the gap between law and life's changing reality, without changing the statute itself. The statute remains as it was, but its meaning changes, because the court has given it a new meaning that suits new social needs". ${ }^{46}$ It also admits any kind of argument which has the objective of implementing the needs of the social system, taking into account both its development and constancy (dynamics and statics). An interpretation of this type always (even indirectly) refers to social needs and interests whose limits and social role are, however, defined by the constitution. Similarly, interpretation decisions of this type are based on the constitution, rulings of constitutional courts and objectives of the state policy to a much greater extent than in the case of the model of interpretation as a closed process. The final content of a judicial decision is primarily determined by the objectives, values and rules of the system of law. They extend beyond the text and frequently boil down to adjudicating on values.

C. Hybrid model of interpretation. It is characteristic of unstable systems of law which are undergoing numerous interactions. A lawyer-interpreter operates in a social vacuum of principles and values. Although, officially, the values and principles are included in legal texts (especially in the constitution), in reality they are not fully expressed

\footnotetext{
45 It is a reference to the so-called exegetical school of interpretation (école de l'exégèse) established in the wake the 1804 civil code in France. See for example R. Siltala, Law, Truth, and Reason: A Treatise on Legal Argumentation, Dordrecht - Heidelberg - London - New York 2011, pp. 138ff.

46 A. Barak, The Judge in a Democracy, Princeton and Oxford 2006, p. 5.
} 
in ordinary legislation and in the practice of courts - they are not a constituent component of the legal culture. Even the Polish Constitutional Tribunal, which in the constitutional principle of the "democratic rule of law" argued dozens of detailed principles of creating and applying the law ${ }^{47}$, avoids clear determinations of the idea of equality, social justice, relationships between the church and the state, the idea of common good and the interests of individuals.

In this state of affairs, interpreters do not reach out for arguments which formulate ratio decidendi judgments, but try to assign such importance to a provision which will enable it to become a premise for legal syllogism and the basis for a court judgment. This is not the same by any means. The avoidance of ratio decidendi analyses means "strategic" avoidance of the issues of justice, fairness, or values in general. It is accompanied by a tacit assumption made by an interpreter that values and principles were previously decided by the legislature when expressing its position in the provisions of the law. If we observe departures from textualist approaches to judicial decision-making (formalistic, associated with hard positivism), they concentrate on purposive (teleological) interpretation rather than on external values or public policies. ${ }^{48}$ According to the latter, the will of a lawgiver matters, not more creative activity of courts.

This type of approach is also implicitly an attempt to reconcile the idea of rationality of the legislation with its frequent actual irrationality or ad hoc orientation. Making reference to selected theses of jurisprudence also replaces the need for a thorough and coherent interpretation of the law as a whole, law as a legal order, bearing in mind specific social circumstances of a case. Furthermore, the achievement of the objective of a judge (court) by reference to earlier higher (or supreme) court rulings would be an operation which is, by all means, correct, if it were to be accompanied - as we wrote - by a reliable reconstruction of the court's position. However, in the case of the "hybrid interpretation of the law" as it is the objective of quoting earlier rulings is different. The only purpose of quotations is to demonstrate that the court has dealt with the matter. In fact, the outcome could be different to that which is suggested by quotations. Hybrid interpretations of the law (lack of guiding line - ratio decidendi) are admittedly difficult to reconstruct, but relatively easy to diagnose in empirical research - they justify not so much the reasoning of a judgment (interpretation), as the reasoning of a provision of the law. This approach may be qualified as a "new textualism", still very close to legal texts, and looking back rather than ahead.

It is not easy to summarize practical relevance of each model. The model of interpretation as a closed process seems to dominate in Poland, where the system

\footnotetext{
47 M. Safjan, former president of the Constitutional Tribunal, describes the role of the Tribunal in the following way: "In fact, jurisprudence became the independent source of new normative principles and values (which had not previously existed in the legal system), injected into the system by creative and axiologically directed judgments. To illustrate, such basic principles might include: the right to a fair trial, dignity of each human person, the right to fair legislation (consisting of a No.No. of different elements belonging to the "interior morality of law" conforming to Fuller's approach, such as the legal security of citizens or the interdiction of the retroactivity of laws), the right to privacy, etc.". See: M. Safjan, Transitional Justice: The Polish Example, the Case of Lustration, "European Journal of Legal Studies" 2, p. 4. M. Safjan claims that the Constitutional Tribunal is equality creative and activistic in determining content of much more ethically involved ideas, such as "justice" or "human dignity", however his opinion supports the text published shortly after the enactment of the Constitution of 1997 (P. Winczorek, Axiological Foundations of the Polish Constitution, in: Constitutional Essays..., pp. 59-71).

48 An example of this approach may be found in: M. Smolak, Activism of Constitutional Courts and purposive interpretation - Remarks on parliamentary democracy in: www.icl-journal.com, 2011/2, pp. 211-217.
} 
of law is still a closed system. This is confirmed by studies of the decisions of administrative courts; it transpired that over $70 \%$ interpretations are linguistic-logical interpretations. This assertion also applies to the interpretations of other courts: common courts and the Supreme Court. However, the practice of reaching out for a hybrid interpretation can be noticed increasingly frequently in the jurisprudence of Polish courts. This is most typical of the rulings of the Constitutional Tribunal. It is also dominant in expert studies and legal opinions formulated during the legislative process.

\section{Practical sophism or "newer rhetoric"?}

There is no doubt that electronic legal databases are useful and even necessary. However, the condition of any interpretation is the knowledge of the applicable legislation. It is difficult today to imagine the use of official journals in a situation where the law is - as in the case of Poland - amended so often that it even happens during the $v a$ catio legis. What, therefore, is the reason for us mentioning negative phenomena as the effects of the widespread use of legal databases? This is primarily determined by: a) the nature of a given legal system, b) the model of legal education, c) the functioning political system, and d) the challenges of globalization.

a) To what extent do the features of a legal system influence the fact that databases prove to be dysfunctional to legal practice? It is easy to notice that this comment primarily applies to "closed" systems of law, which are dominated by the syllogistic model of application of the law and the respect for judicial formalism. In such systems, in practice, much less importance is attached to values, philosophical attitudes and the principles of the law. The result of this state of affairs is inability to agree on the directives of interpretation which need to be applied in a situation of divergent results of the interpretation. In such legal systems, databases function in a kind of axiological vacuum. This is particularly noticeable in countries (such as Poland) whose legal system is in a phase of constant transformation. This supports instrumentalization of the law and increase in discretionary power of judges.

b) To what extent is the model of education of lawyers "responsible for" the negative effects of using databases? It seems that legal databases increasingly highlight internal richness of a legal order, perhaps even a plurality of sources of the law. Similarly, databases undermine the conviction that only the standards contained in legal acts are the law. Meanwhile, in the education of the legal profession in Poland, the assumption is made that the law is limited to the mere provisions of the law. A judge is to be merely a Montesquieu's legal machine, while the sphere of values is to be the domain of legislature and politicians. The failure in adopting the model of education based on students working out the solutions to various difficult cases, and the lack of emphasis on the importance of legal principles (in the R. Dworkin's or R. Alexy's sense) resembles the Odysseus' decision, whereby, in order to avoid the enchanting singing of the Mermaids, he blocked the ears of his crew and had ordered himself to be lashed to the mast of his ship.

Such educational practice is also reinforced by the representatives of legal doctrine or "legal sciences". Even if they are familiar with various theories of inter- 
pretation of the law or practical experience of other legal systems, most of them behave like Odysseus: he knows the song of the Mermaids, but does not dare to critically look at the reality, and prefers to wait for the confirmation of his opinions in legal practice rather than trying to change it. ${ }^{49}$ The opportunism of judges avoiding brave decisions in the application of the law is supported by the opportunism of legal sciences. But perhaps this is an inevitable feature of "countries in transition" (countries undergoing the process of fundamental political and economic changes): if we changed the foundations of the social order, everyone would prefer to look for fixed points rather than further derogations and exceptions to fundamental rules.

c) To what extent is a political system responsible for the dysfunctions of databases? In the case of Poland, to much a higher extent than it could be imagined. This was demonstrated by the events such as those in 2007, when there was an open attack by the politicians on the Constitutional Tribunal for its judicial activism and for preferring functional interpretations of the law. ${ }^{50}$ None of the observers of the Polish political scene stated that the construction of a democratic state of law had been completed in Poland. However, nobody wants to admit that the nihilistic attitudes towards the law are a common feature of Polish politicians and deputies. Politicians expect a "correct" interpretation of the law from judges, namely such an interpretation which reflects their interests and political intentions. This type of situation reinforces formalistic attitudes among lawyers, which enable them to avoid charges of taking on the role of lawmakers.

d) To what extent is the phenomenon of globalization responsible for the dysfunctions of databases? In our opinion, to a greater extent than it is believed. The reasons are not the process of convergence or even unification of the systems of law, to which many authors draw attention. The fundamental problem lies in a permanent supply of an increasing number of regulations created by supranational organizations to national legal systems. This not only leads to the inflation of law and the instrumental nature of these regulations. A greater problem is their thoughtless implementation by lawmakers, frequently being incomprehensible, not only for the lawyers but also for the citizens. Consequently, despite reflecting the technical and procedural content of the norms, legal databases poorly present the detailed arguments standing behind their adoption and implementation. Databases do not contain guidelines for the interpretation of detailed regulations and thereby only provide half the necessary knowledge to lawyers. Paradoxically, therefore, legal databases will only be an effective tool in legal practice when they are supplemented with thorough comparative, economic, political, etc. knowledge.

At the end we should face the most difficult questions: does the use of electronic databases by Polish lawyers lead to a new kind of legal rhetoric, new concepts

49 In the field of legal theory we can find, fortunately, a few exceptions to this general practice: M. Zieliński with his defense of "derivational" theory of legal interpretation, M. Zirk-Sadowski with his hermeneutic concept of lawyers' participation in culture, E. Łętowska with her idea of "multicentrism of legal system" or M. Matczak criticizing legal formalism.

50 On legal "impossibilism" see for example M. Safjan, Transitional Justice ..., p. 19; W. Sadurski, Constitutional Courts and Constitutional Culture in Central and Eastern European Countries, in: Central and Eastern Europe After Transition: Towards a New Socio-Legal Semantics, edited by A. Febbrajo, W. Sadurski, Aldershot 2010, p. 111; T. Stawecki, W. Staśkiewicz, J. Winczorek, Between Polycentrism and fragmentation..., pp. 27, 62. 
and practice of matured legal argumentation making step forward to the Chaim Perelman's "new rhetoric", announced already fifty years ago, or what we face is only an example of practical sophism, the use of elegant arguments in order to deceive an auditorium, lawyers and public opinion? A serious answer to these questions would require empirical research to be conducted. It is, at least at the moment, out of reach of the authors of this paper. We hope, however, that reflections presented herein provide the readers with the first collection of hypotheses. 


\section{BIBLIOGRAFIA / REFERENCES:}

Barak, A. (2006). The Judge in a Democracy. Princeton: Princeton University Press.

Bodnar, A., Frankowski, S. (2005). Introduction to Polish Law. Hague: Kluwer Law International.

Brzezinski, M.F. (1998). The Struggle for Constitutionalism in Poland. Basingstoke-London: Macmillan Press.

Cotterrell, R.B.M. (2006). Law, Culture and Society: Legal Ideas in the Mirror of Social Theory. Aldershot: Routledge.

Dajczak, W., Szwarc, A.J., Wiliński, P. (2011). Handbook of Polish Law. Warszawa: ParkPrawo.

Fijałkowski, A. (1999). The Judiciary’s Struggle towards the Rule of Law in Poland. In J. Přıbáň, J. Young (Eds.), The Rule of law in Central Europe. The Recostruction of Legality, Constitutionalism and Civil Society in the Post-Communist Countries. Dartmouth: Routledge.

Finnis, J. (2011). Philosophy of law. Collected Essays: Volume IV. Oxford: Oxford University Press.

Galligan, D., Matczak, M. (2005). Strategies of judicial review. Exercising judicial discretion in administrative cases involving busi-ness entities. A report prepared under the Ernst \& Young Program "Better Government". Warszawa: Foundation for Law, Justice and Society.

Garlicki, L. (1999). The Principles of the System of Government in the Republic of Poland. In A. Pol, P. Sarnecki, A. Szmyt, Z. Witkowski (Eds.), The Principles of Basic Institutions of the System of Government in Poland. Warszawa: Sejm Public Office.

Golecki, M.J. (2011). Między pewnościa a efektywnościa. Marginalizm instytucjonalny wobec prawotwórczego stosowania prawa. Warszawa: Wolters Kluwer.

Gołębiowski, M., Kube, M., Sześciło, D., Rzymska, P. (2012). E-sądy po polsku. Badanie i ranking stron internetowych sadów okregowych $i$ apelacyjnych oraz Sąu Najwyższego i Trybunału Konstytucyjnego. Warszawa: Instytut Prawa i Społeczeństwa.

Górnicki, L. (2000). Prawo cywilne w pracach komisji kodyfikacyjnej Rzeczypospolitej Polskiej w latach 1919-1939. Wrocław: Kolonia Limited.

Janowski, J. (2011). Informatyka prawa. Zadania $i$ znaczenie $w$ zwiazku z ksztaltowaniem się elektronicznego obrotu prawnego. Lublin: Wydawnictwo Uniwersytetu Mari CurieSkłodowskiej.

Janowski, J. (2011). Informatyka prawnicza. Warszawa: C.H. Beck.

Łętowska, E. (1999). Courts and Tribunals under the Constitution of Poland. In M. Wyrzykowski (Ed.), Constitutional Essays. Warszawa: Institute of Public Affairs.

Łętowska, E. (2005). Między Scyllą a Charybdą - sędzia polski między Strasburgiem i Luksemburgiem. Europejski Przeglad Sadowy 1, 3-10.

Łętowska, E. (2005). Multicentricity of the Contemporary System of Law and its Consequences. The Polish Foreign Affairs Digest 5/2, 107-116.

Łętowska, E. (2005). Multicentryczność współczesnego systemu prawa i jej konsekwencje. Państwo $i$ Prawo 4, 3-10.

MacCormick, N. (2007). Institutions of Law. An Essay in Legal Theory. Oxford: Oxford University Press. 
MacCormick, N. (2005). Rhetoric and the Rule of Law. A theory of Legal Reasoning. Oxford: Oxford University Press.

Mańko, R. (2005). The Culture of Private Law in Central Europe After Enlargement: A Polish Perspective. European Law Journal 11/5, 527-548.

Matczak, M., Bencze, M., Kühn, Z. (2010). Constitutions, EU Law and Judicial Strategies in the Czech Republic, Hungary and Poland. Journal of Public Policy 30/1, 81-99.

Matczak, M. (2007). Summa Iniuria. O błędzie formalizmu w procesie stosowania prawa. Warszawa: Scholar.

Misztal-Konecka, J., Tylec, G. (2012). Ewolucja prawa polskiego pod wptywem technologii informatycznych. Elektroniczne aspekty wymiaru sprawiedliwości. Lublin: Wydawnictwo KUL.

Morawski, L. (2006). Czy sądy mogą angażować się politycznie? Państwo i Prawo 3, 6-23.

Morawski, L. (1999). Positivist or Non-Positivist Rule of Law? Polish Experience of a General Dilemma. In A. Krygier, A. Czarnota (Eds.), The Rule of Law after Communism. Problems and Prospects in East-Central Europe. Aldershot: Brookfield.

Morawski, L., Zirk-Sadowski, M. (1997). Precedent in Poland. In N. MacCormick, R.S. Summers (Eds.), Interpreting Precedent: A Comparative Study. Aldershot: Dartmouth.

Morawski, L. (2009). Zasada trójpodziału władzy. Trybunał Konstytucyjny i aktywizm sędziowski. Przeglad Sejmowy 4, 59-74.

Paparrigopoulos, X.J. (1988). The Role of Courts in Crisis and Transition Periods: Courts as Image Makers. In S. Shetreet (Ed.), The Role of Courts in Society. Dordrecht: M. Nijhoff Publishers.

Perelman, C. (1980). Justice, Law, Argument. Essays on Moral and Legal Reasoning. DordrechtBoston: D. Reidel.

Piana, D. (2010). Judicial Accountabilities in New Europe. From Rule of Law to Quality of Justice. Aldershot: Routledge.

Pietruch-Reizer, D. (1992). Rozwój środków przekazu informacji o prawie. Katowice: Śląski Instytut Naukowy.

Podgórecki, A. (1974). Law and Society. London: Routledge \& Kegan Paul.

Porat, A. (2000). Enforcing Contracts in Dysfunctional Legal Systems: The Close Relationship between Public and Private Orders: A Reply to McMillan and Woodruff. Michigan Law Review 98/8, 2459-2480.

Přıbán̆, J. (2005). Constitutional Symbolism and Political (Dis) continuity: Legal Rationality and Its Integrative Function in Post-communist Transformations. In A. Czarnota, M. Krygier, W. Sadurski (Eds.), Rethinking the Role of Law after Communism. Budapest-New York: Central European University Press.

Sadurski, W. (2010). Constitutional Courts and Constitutional Culture in Central and Eastern European Countries. In A. Febbrajo, W. Sadurski (Eds.), Central and Eastern Europe After Transi-tion: Towards a New Socio-Legal Semantics. Aldershot: Routledge.

Sadurski, W. (2002). Legitimacy and Reasons of Constitutional Review after Communism. In W. Sadurski (Ed.), Constitutional Justice, East and West. Democratic Legitimacy and Con-stitutional Courts in Post-Communist Europe in a Comparative Perspective. Hague-London-New York: Kluwer Law International. 
Safjan, M. (2010). The Universalisation of Legal Interpretation. In J. Jemielniak, P. Mikłaszewicz (Eds.), Interpretation of Law in the Global World: From Particularism to a Universal Approach. Heidelberg: Springer.

Sartor, G. (2011). Introduction: ITC and Legislation In the Knowledge Society. In G. Sartor, M. Oalmirani, E. Francesconi, M. A. Biasiotti (Eds.), Legislative XML for the Semantic Web. Principles, Models, Standards for Document Management. Dordrecht: Springer.

Siltala, R. (2011). Law, Truth, and Reason: A Treatise on Legal Argumentation. Dordrecht: Springer.

Staśkiewicz, W. (2007). Prawo jako narzędzie polityki państwa okresu przemian (przeszłość wobec przyszłości). In M. Zubik (Ed.), Prawo i polityka: materiały z konferencji Wydziału Prawa $i$ Administracji Uniwersytetu Warszawskiego, która odbyła się 24 lutego 2006 roku. Warszawa: Liber.

Staśkiewicz, W. (2006). Rec.: B.Z. Tamanaha, On the Rule of Law. History, Politics, Theory, Cambridge 2004. Przeglad Sejmowy 2, 158-162.

Stawecki, T., Staśkiewicz, W., Winczorek, J. (2009). Between Polycentrism and fragmentation. The Impact of Constitutional Tribunal Rulings on the Polish Legal Order. A report prepared under the Ernst \& Young Program Better Government). Warszawa: Ernst \& Young Poland.

Stawecki, T. (2009). Independence of the legal professions and the rule of law in post-communist society. In T. Wardyński, M. Niziołek (Eds.), Niezależność sądownictwa i zawodów prawniczych jako fundamenty państwa prawa. Wyzwania wspótczesności. Warszawa: LexisNexis.

Stawecki, T. (2010). Precedens w polskim porządku prawnym. Pojęcie i wnioski de lege ferenda. In A. Śledzińska-Simon, M. Wyrzykowski (Eds.), Precedens w polskim systemie prawa. Warszawa: Zakład Praw Człowieka WPiA UW.

Stawecki, T. (2005). Rejestry publiczne. Funkcje instytucji. Warszawa: LexisNexis.

Stawecki, T. (1999). Secured Transactions in Poland: Coping with the Traditional Thinking and the New Challenges for Central and Eastern Europe. Uniform Commercial Code Law Journal 32/1, 2555 .

Stawecki, T. (2007). Sędziowie w procesie reformowania prawa. In J. Stelmach, M. Soniewicka (Eds.), Analiza ekonomiczna w zastosowaniach prawniczych. Warszawa: Wolters Kluwer.

Studnicki, F. (1978). Wprowadzenie do informatyki prawniczej. Zautomatyzowane wyszukiwanie informacji prawnej. Warszawa: Państwowe Wydawnictwo Naukowe.

Studnicki, F. (1974). Wstep do informatyki prawniczej. Automatyczne systemy wyszukiwawcze. Lublin: Towarzystwo Naukowe Organizacji i Kierownictwa.

Tamanaha, B.Z. (2004). On the Rule of Law. History, Politics, Theory. Cambridge: Cambridge University Press.

Wojciechowski, B. (2010). Discourse Ethics as a Basis of the Application of Law. In J. Jemielniak, P. Mikłaszewicz (Eds.), Interpretation of Law in the Global World: From Particularism to a Universal Approach. Heidelberg: Springer.

Wojciechowski, B. (2004). Dyskrecjonalność sędziowska. Studium teoretycznoprawne. Toruń: Wydawnictwo Adam Marszałek.

Wróblewski, J. (1979). A Model of Rational Law-Making. Archiv für Rechts- und Sozialphilosophie 65/2, 187-201. 
Wróblewski, J. (1981). Law as an Instrument of Social Homeostasis. Archiv für Rechts- und Sozialphilosophie 67/1, 1-13.

Wróblewski, J. (1974). Legal Syllogism and Rationality of Judicial Decision. Rechtstheorie 5/1-2, 3346.

Wróblewski, J. (1990). Principles, Values and Rules in Legal Decision-Making and the Dimensions of Legal Rationality. Ratio Juris 3/1, 100-117.

Zirk-Sadowski, M. (2009). Soft Kelsenism versus Multicentrism: Some Remarks on Theoretical Foundations of European Law. In M. Zirk-Sadowski, M. Golecki, B. Wojciechowski (Eds.), Multicentrism as an Emerging Paradigm in Legal Theory. Frankfurt: Peter Lang. 